FACTA UNIVERSITATIS

Series: Teaching, Learning and Teacher Education Vol. 4, No 1, 2020, pp. 47 - 56

https://doi.org/10.22190/FUTLTE2001047M

Review article

\title{
DEVELOPMENT OF INTERCULTURAL EDUCATION COMPETENCIES IN TEACHERS
}

UDC 316.722:37.03; 37.017:316.7; 371.13

\section{Marija Marković, Anastasija Mamutović, Zorica Stanisavljević Petrović}

\author{
University of Niš, Faculty of Philosophy, Serbia
}

\begin{abstract}
Intercultural education constitutes an integral part of the education system reform currently being undertaken in our country. This paper shall indicate the competencies that teachers are required to develop to successfully implement the concept of intercultural education. Special attention shall be paid to analyzing key elements that initial training for intercultural education at Teachers' Training Faculties should comprise, bearing in mind that developing intercultural competencies in teachers constitute the basis for developing such competencies in students. Apart from providing them with a high-quality initial education, to develop the required competencies in teachers one also needs to furnish them with continuing professional development. The paper shall emphasize the importance of developing specific teaching competencies, and it shall point to various assumptions regarding successful teaching activities aiming at the development of intercultural education.
\end{abstract}

Key words: interculturalism, intercultural education, intercultural competencies of teachers, teacher training for interculturalism

\section{INTRODUCTION}

In a modern global society characterized by permanently growing complexity in interpersonal relationships, intercultural education and development of intercultural competencies are becoming increasingly important issues even within our school system. In addition to successful communication skills, students should also develop intercultural awareness, sensitivity and understanding of the behavior of others, their worldviews and their manner of thinking (Hrvatić \& Piršl, 2005). Such an approach does not merely pertain to respect for diversity and exercise of human rights of migrants and members of national minorities, but also to the well-being of all students.

Received January 8, 2020/Accepted April 1, 2020

Corresponding author: Marija Marković

Faculty of Philosophy, University of Niš, Ćirila i Metodija 2, 18000 Niš, Serbia

Phone: +381 18514 312•E-mail: marija.markovic@filfak.ni.ac.rs 
Intercultural education does not necessarily imply the introduction of a new teaching course. It rather implies the integration of elements of intercultural education into the primary education process and their implementation within the available teaching courses (Perotti, 1995; Hercigonja, 2017). It is, therefore, necessary to adequately train teachers for a successful realization of the presented concept of intercultural education.

\section{THEORETICAL ORIENTATION}

\subsection{The concept of interculturalism - clarification of terms}

In literature one encounters the use of various terms which denote interculturalism, but which provide the same, similar or even different meanings of the same term such as the following: intercultural education, multicultural education, inclusive education, transformative education, education for diversity, education for social justice. The authors of this paper opted for the use of term intercultural education which implies more than simple awareness of diversity and comprises openness towards, respect for and acceptance of those who are perceived as different (Carignan, Sanders \& Pourdavood, 2005; Hrvatic \& Piršl, 2005). Interculturalism is related to interaction, i.e. establishing, developing and building relationships between cultures (Hercigonja, 2017). In contrast, multicultural education aims to enable one to accept or at least tolerate other cultures by learning about them (Gošović, 2009; Hercigonja, 2017). One can, therefore, conclude that interculturalism and multiculturalism are not identical terms. One can rather assert that multiculturalism represents a phase preceding interculturalism in society (Hercigonja, 2017).

Intercultural education aims to establish a sustainable manner of co-existence in a multicultural society. This can be achieved by establishing understanding, mutual respect and dialogue among groups which belong to different cultures, as well as by securing equal opportunities for all and by making an effort to prevent discrimination against others who are perceived as different. By encouraging equality and countering injustice and discrimination one promotes the values upon which one could build respect for human rights. Intercultural education presupposes that one's knowledge of one's culture is necessary to understand the culture of others (Šnel, 2008; Gošović, 2009). It is believed that only those individuals who had a thorough knowledge of their own culture would not feel fear of diversity and would thus be ready to take a positive stance towards cultural exchange. In this instance, cultures are not observed as closed homogenous entities but as open systems of rules which mutually build each other, imply the exchange and undergo permanent changes. A relationship can be considered intercultural: 1) if the key notions are understood as relational, i.e. if their meaning can be understood only in the context of human interaction, (2) if in an attempt to understand others one also attempts to understand one's position and standpoint, (3) if such a relationship leads to self-awareness through distancing and self-criticism, (4) if the self-criticism results in a change in oneself and (5) if such a change results in a qualitatively new relationship between cultures (Šnel, 2008).

\subsection{Intercultural competencies in teachers}

It is necessary to develop suitable competencies in teachers to sufficiently empower them to implement the concept of intercultural education. Teachers' competencies for intercultural education constitute an important element of one's personal and professional 
development (Drandić, 2012). The complexity of a teacher's role in the process of intercultural education is reflected in the fact that teachers are expected to be associates, creators, and moderators of intercultural relationships, as well as to apply suitable forms of teaching which would contribute to creating a climate of mutual understanding, intercultural sensitivity, equal interaction and collaborative learning in the classroom. An intercultural approach is based on the knowledge, acceptance and recognition of diversity and openness towards it, while teachers' acquired intercultural competencies can be observed as the basis of an efficient intercultural education (Bedeković \& Zrlić, 2014). Teachers' intercultural competencies can primarily be defined as an orientation which directs one's way of thinking and behaving, rather than a simple set of individual skills. The aforementioned competencies can surely be observed through properties such as attitudes, knowledge, skills, and actions. Intercultural competence involves cognitive (knowledge, attitudes), emotional and behavioral dimensions (skills) (Hrvatić \& Piršl, 2005; Piršl, 2005; Jokikokko, 2009). It is manifested in certain emotional and cognitive abilities, as well as in a flexible behavior and communication, in empathy and motivation to adjust, and in accepting different perceptions of reality. Intercultural competence includes the ability to establish and maintain mutual relationships, a form of communication with the lowest level of misconception, as well as the readiness to achieve common goals. Positive behavioral characteristics such as respect, patience, sense of humor, flexibility, empathy, openness, and curiosity constitute the properties of a person versed in intercultural communication. None of the three aforementioned dimensions act independently. They rather complement and depend on each other (Bedeković \& Zrlić, 2014; Hercigonja, 2017). The level of intercultural competence of each person or a group is determined by the quality of behavior in a specific intercultural interaction which is by and large determined by the aforementioned dimensions (Hercigonja, 2017).

In literature, one can encounter various classifications of teachers' intercultural competencies. For example, McPherson (2010) classifies teachers' intercultural competencies into following dimensions: constructed teachers' attitudes (understanding all students, having high expectations of all students, attributing students' failure to a teacher's inadequate teaching approach, etc.), competencies related to cultural sensitivity (including cultural knowledge and perspectives of immigrants in the curriculum), competencies relating to teaching and curriculum implementation (cultural classroom activities, intercultural contacts), competencies related to intercultural communication (intercultural communication competencies which encompass intercultural communication in the teaching process, intercultural listening and considering the influence of power: bilingual and contextual teaching) and critical inclinations (awareness of the power and privileges of the majority; assumptions of a cultural deficit of migrants and the members of minority groups).

Development of intercultural competencies in teachers implies the following: good knowledge and continuous learning of one's culture and cultures of other people; a welldeveloped ability to communicate in a humane and quality manner; respect for and acceptance of students from other cultures; a high level of tolerance and empathy; developed self-respect and self-confidence; curiosity and openness towards new knowledge and experience; the awareness of numerous negative consequences created by race and national discrimination, both for victims and perpetrators; struggle against prejudice and stereotypes (Đuranović \& Klasnić, 2012). 


\subsection{Teacher training for intercultural education}

A teacher's role in the process of intercultural education is reflected in empowering one's intercultural identity and modeling one's pedagogical activity which would result in enabling a consistent implementation of intercultural principles in a direct educational practice (Bedeković \& Zrlić, 2014). Enabling teachers to implement intercultural education can be achieved through quality pedagogical, psychological, didactic and professional education which will equip one with considerable flexibility, creativity and adjustment to complex and demanding educational situations (Hrvatić \& Piršl, 2005). Therefore, during teachers' initial education one should focus on the development of teachers' intercultural competencies whereby one should pay attention to the quality of training provided during the studies on Teachers' Training Faculties. Müller (2001) indicates basic preconditions for efficient training in the domain of intercultural education:

- It is necessary to have general conditions of intercultural teachers' education curriculum: a) intercultural education should constitute a mandatory part of training for all teachers; b) it should be highly represented with a larger number of classes per semester during several years of study; c) aside from acquiring knowledge prospective teachers should also be provided with an opportunity to acquire practical knowledge in different contexts (monolingual teaching, classes for foreign language speakers, career guidance for the children of migrants, etc.); d) adequate planning and co-ordination of the manners of acquiring theoretical and practical knowledge in this field during one's studies; e) the quality of study programs should be monitored based on internal (teaching competencies) and external (academic achievements of immigrant children) indicators; f) providing prospective teachers with the possibility of specializing in the field of intercultural education; g) institutions dealing with teachers' training need to influence educational policies of the country by participating in the work of local and national educational bodies to increase the academic achievement of immigrant students; $h$ ) organizing various forms of professional development of teachers upon the completion of their initial education in the domain of intercultural education.

- It is necessary to have an orientation towards acquiring teaching qualifications in the following five fields which aim to develop teachers' intercultural competencies: 1) competencies in the field of teaching and learning (didactic competencies, diagnostic competencies, competencies in the field of students' integration and communication, psycholinguistics qualifications in the field of multilingualism and multiculturalism, qualifications related to students'age and personality traits); 2) basic sociological knowledge of the process of immigration (heterogeneity as a social situation: multilingualism and multiculturalism, the current state of affairs and importance attached to the social policy regarding immigrants, heterogeneity versus homogeneity); 3) comprehensive competencies of providing advice and making decisions (competencies for working with immigrant parents, skills of career guidance and decision-making, competencies in the field of marketing, skills of decision-making, cooperation with advisory bodies outside schools); 4) individual experience with multiculturalism and multingualism (linguistic awareness and cultural awareness, awareness of discrimination - racism and discrimination on daily basis, history of immigration of specific ethnic groups, cooperation with immigrants' native language teachers); 5) specific skills in the field of encouraging students' academic achievements (an analysis of academic achievements, a change in the selection system, specific possibilities related to the choice of career for immigrant students). 
In order to develop the aforementioned competencies, a teacher training curriculum for interculturalism should encompass the following: 1) a historical approach to migration trends and information and migration in general; 2) a thorough ethno-sociological study, as well as comparing different systems of cultural references which prospective teachers could discover in their students; 3 ) a research approach to the media so that teachers could better understand the media and use them to illustrate a specific topic, and include various manners in which certain topics are represented in the media in the process of teaching (this would relate their work to real life situations and to the existing knowledge of their students); 4) a comparative study of educational systems which should not be limited to a description of school systems in different countries, but offer a description of values upon which those school systems are based; 5) deeper knowledge of human rights (concepts, history, international and national instruments, actions), as well as specifying the cause of intolerance and xenophobia; 6) a sociolinguistic approach to language and research into its role in the cultural identity of a child; 7) introducing notions which originate in linguistics and psycholinguistics into language teaching (especially in the process of learning); 8) study (in the process of language teaching) of a two-fold language function: language as an instrument of communication, an instrumental form of knowledge which enables one to master other forms of human knowledge and technology advancement (language as a tool), as well as language as a source of identity rooted in culture, religion, family (native language or first language); 9) knowledge of the sociology of culture: permeability and rigidity of cultures, their symbolic aspects, balance of power between different cultures; 10) re-examination of the nature and importance of school evaluation of behavior, knowledge and abilities; 11) seeking more equitable forms of evaluation which would take into consideration the differences in students' cultural traits and manners in which students perceive the process of learning; 12) knowledge of the real position of immigrants (economic, social and legal position; diversity of statuses and groups; relationships with the native population); 13) real contacts with immigrant and native communities as a manner of improving the co-operation with students' families; 14) participation in multicultural teams, because it is important to have immigrants not merely among the consumers of services, but also among the providers who have considerable knowledge of the aforementioned services (Perotti, 1995).

Certainly, for teachers (as well as prospective teachers) to be efficient in teaching immigrants or national minorities it is, therefore, necessary to raise awareness regarding their attitudes, as well as regarding their potential prejudice and stereotypes about the given ethnic groups (Perotti, 1995; McAllister \& Irvine, 2000; Banks, 2001; Jokikokko, 2009; Chu \& Garcia, 2014; Fives \& Buehl, 2016; Vranješević \& Frost, 2016; Whitaker \& Kenny, 2016; Cherng \& Davis, 2017).

Furthermore, it is necessary to develop suitable beliefs in teachers regarding the phenomenon of cultural diversity (Fives \& Buehl, 2012), which can be placed in five related fields: (1) beliefs about one's cultural self-efficiency which deals with teachers' perceptions of themselves as competent persons concerning the appreciation of cultural diversity in the classroom, (2) beliefs about the cultural context and environment, such as beliefs about the efficiency of the teaching process implemented in highly cultural and ethnically diversified schools and different geographical areas, (3) beliefs about cultural content and knowledge which relate to beliefs about the content of teaching - what should students be taught in the context of teaching courses (4) beliefs about culturally sensitive teaching practices and approaches and (5) beliefs about culturally different 
students and their families. The aforementioned beliefs shall influence a teacher's attitude towards students belonging to minority groups (Civitillo, Juang \& Schachner, 2018). Furthermore, teachers should develop beliefs in students that relate to recognizing the advantages of cultural diversity (Civitillo, Juang \& Schachner, 2018).

To provide all students with equal opportunities to achieve academic success it is necessary to train teachers to take different cultures, languages, backgrounds and students' abilities into account while planning and implementing the teaching process as well as to act accordingly while performing their teaching activities (Perotti, 1995; Gay, 2000; Ewing, 2001; Müller, 2001; Jokikokko, 2009; Chu \& Garcia, 2014). Bearing in mind population migrations, such training should also encompass English or other foreign language learning for integration and more efficient education of students who have become a part of our country's education system (Whitaker \& Kenny, 2016). It is, therefore, important to take care of the native language of migrants and national minorities (e.g. Müller, 2001; Hrvatić, 2007). Academic deficiency of migrant children in a monolingual education system represents a serious issue, because it can cause discrimination in the school system. Should a student fail to master to a high degree the language of the school system that he/she had become a part of, he/she would be characterized as academically unsuccessful.

Five important elements of culturally responsive teaching are as follows: a) a teacher's adoption of various knowledge of cultural diversity (of cultural values, tradition, communication, learning styles, contribution to the development of mankind and patterns of interpersonal communication typical of different ethnic groups); b) designing culturally relevant curricula (including the content relating to other ethnic and culture groups into the curriculum, as well as enabling students to resort to a critical reconsideration of the existing social practice concerning one's relationship towards the members of other cultures); c) showing care for the members of other cultures and making efforts to form a community of learning in the classroom (creating an atmosphere in the classroom which is suitable for ethnically different students, requiring high achievements from all students, emphasizinga holistic approach and integrative learning); d) intercultural communication (respect for linguistic specificities of students, understanding how students' intellectual development is culturally coded and under a strong influence of cultural socialization regarding the styles of communication, respect for different communication styles in students); e) respect for ethnic diversity in the process of teaching (harmonizing teaching procedures and learning styles of different students) (Gay, 2000). It is necessary to enable teachers to integrate the given elements in the process of planning and implementing the teaching content to all courses for realizing intercultural education, as well as for achieving academic success in all students. Naturally, one should bear in mind that the given list is not considered final and that it can be expanded.

Therefore, it is necessary to train teachers to respect and integrate cultural and linguistic properties of students for implementing culturally and linguistically relevant classroom contexts (Gay, 2002; Jokikokko, 2009; Chu \& Garcia, 2014). It is necessary to understand that the acquisition of a specific language carries certain specificities regarding the development of cognitive, academic and linguistic skills that are culturally conditioned. Hence, teachers should apply various teaching strategies for honoring different learning styles in students. Likewise, migrants and national minority members shall become more successful in the process of education if a teacher's approach to teaching honors the cultural and linguistic properties of the given social groups (Chu \& Garcia, 2014). 
It is necessary to train prospective teachers to critically reconsider the current school practice relating to the recognition of factors which render the implementation of the concept of intercultural education more difficult and lead to discrimination against the children of migrants and members of national minorities (power imbalance, domination and better social positions of the majority). Teachers should also be trained to fight against prejudice and discrimination against national minorities and migrants in a narrower and wider social context (McAllister \& Irvine, 2000; Ewing, 2001; Müller, 2001; Gay, 2002; Carignan, Sanders, \& Pourdavood, 2005; Gošović, 2009; Jokikokko, 2009; Hollins, 2011; Vranješević \& Frost, 2016). Teachers should be ready to identify school policies and practice which encourage hegemony, and which impede school achievements and improvement of the social status of students who are constantly denied approaches to different educational opportunities. It is necessary to train teachers to nurture multiple perspectives, as well as to apply multiple principles and practice which stem from a reflexive manner of thinking (Ewing, 2001; Hollins, 2011; Vranješević \& Frost, 2016). It is, therefore, important to create an atmosphere of critical thinking during studies to enable one to reconsider the existing social context/one's attitudes, as well as to develop important skills to implement intercultural education (open mind for others, empathy, tolerance), as opposed to the mere acquisition of the knowledge of interculturalism (Lanas, 2014).

It is also necessary to bear in mind that, during their initial education, numerous teachers fail to acquire competencies in the field of intercultural education which in the context of globalization and modern social trends becomes increasingly necessary. Therefore, aside from the development of the intercultural competencies of younger generations of teachers during their initial education, it is necessary to introduce suitable forms of professional development for all teachers (Perotti, 1995; Bedeković \& Zrlić, 2014). Professional development of teachers which can be initiated through everyday practice should contribute to further development of their competencies in the field of intercultural education. Intercultural education can be observed as a lifelong process within which the influence of others is especially important for teachers' intercultural learning (Hrvatić, 2007; Jokikokko, 2009). Teachers' profession should be observed as a perpetual effort that encompasses both initial education and further professional development (improvement), based on the principles of lifelong learning that include both formal and informal education.

Based on the analysis of how certain authors classify teachers' intercultural competencies, we believe that a range of such competencies could be distinguished. Apart from desirable teachers' traits such as respect, patience, empathy, openness, curiosity, and resourcefulness, teachers should also develop the following specific competencies in the field of intercultural education:

- Acquiring knowledge of one's culture and the culture of others;

- Understanding the specificities of one's culture and other cultures, as well as of the importance of their appreciation in the process of education;

- Critical understanding of the relationship between one's culture and other cultures and making an effort to remedy the existing problems in the current practice;

- The flexibility of one's behavior and communication;

- Multiple perspectives;

- Tolerance towards diversity - especially towards cultural diversity;

- Didactic and methodological competencies to understand and respect every student in the process of education, high expectations of all students, self-evaluation of one's teaching process, respect for cultural and ethnic diversity in the context of teaching, 
integration of cultural knowledge into everyday teaching, creating a relevant class context from a cultural and linguistic standpoint, etc.;

- Intercultural communication competencies, etc.

The training for implementing the concepts of intercultural education should not be limited to teachers alone, but extended to all school employees (Perotti, 1995; Hrvatić, 2007; Gošović, 2009). Intercultural education in the context of multiculturalism represents a process that requires the involvement of all participants in the process of education, which encourages equality and respect for the human rights of all students, without discrimination and prejudice. Thus one creates conditions for social pluralism through understanding, respect, and evaluation of similarities and differences, mutual permeation and encouraging contacts among cultures (Drandić, 2010).

\section{FINAL CONSIDERATIONS}

The teaching profession in the context of modern education and upbringing can be considered a very complex profession that requires quality formal education of the teaching staff, as well as continuing professional development through practice. Implementation of intercultural education requires adequate training of the teaching staff so that they could, in turn, develop intercultural competencies in students. The competencies of the teaching staff to implement intercultural education depend on the manner of their training for the required field, whereby teachers' training for intercultural education can be realized during teachers' initial education, as well as by employing various forms of professional development. Therefore, the need to increase the quality of education and professional development of teachers should constitute the priority field of social development.

However, to successfully realize the concept of intercultural education, it is necessary to continually work on improving not merely teachers' competencies for the given field, but also competencies of other school staff members to improve conditions and secure the necessary means, and to improve the cooperation at the level of an institution, etc. It would be misleading to expect a successfully implemented intercultural education in schools in the following situations: if there is no positive atmosphere in the school, if teachers have not acquired the necessary intercultural competencies, if the key actors of the school life do not have positive attitudes towards interculturalism, if there is no adequate cooperation and support among the school staff, etc.

To successfully implement intercultural education it is necessary to encourage further changes in a wider social context regarding the awareness of persons who are perceived as different, removing stereotypes and prejudice towards migrants and members of national minorities, creating circumstances for acquiring positive experience through interactions with others who are perceived as different, etc.

Acknowledgment: The paper is a part of the project "Enhancing professional competencies of prospective pedagogues within the framework of undergraduate academic studies of pedagogy" (360/1-16-5-01), which is carried out at the University of Niš - Faculty of Philosophy. This study was financially supported by the Ministry of Education, Science and Technological Development of the Republic of Serbia. 


\section{REFERENCES}

Banks, A. J. (2001). Citizenship education and diversity - implications for teacher education. Journal of Teacher Education, 52(1), 5-16.

Bedeković, V., \& Zrilić, S. (2014). Interkulturalni odgoj i obrazovanje kao čimbenik suživota u multikulturalnom društvu [Intercultural education as a factor of coexistence in a multicultural society]. Magistra Iadertina, 9(1), 111-122.

Carignan, N., Sanders, M., \& Pourdavood, G. R. (2005). Racism and Ethnocentrism: Social Representations of Preservice Teachers in the Context of Multi - and Intercultural Education. International Journal of Qualitative Methods, 4(3), 1-19.

Cherng, H.-Y. S., \& Davis, A. L. (2017). Multicultural Matters: An Investigation of Key Assumptions of Multicultural Education Reform in Teacher Education. Journal of Teacher Education,70(3), 219-236.

Chu, S.-Y., \& Garcia, S. (2014). Culturally Responsive Teaching Efficacy Beliefs of In-Service Special Education Teachers. Remedial and Special Education, 35(4), 218-232.

Civitillo, S., Juang, L., \& Schachner, M. (2018). Challenging beliefs about cultural diversity in education: A synthesis and critical review of training with pre-service teachers. Educational Research Review, 24, 67-83.

Drandić, D. (2010). Tradicijska glazba u kontekstu interkulturalnih kompetencija učitelja [Traditional music in the context of teachers' intercultural competences]. Pedagogijska istraživanja, 7(1), 95-108.

Drandić, D. (2012). Interkulturalne kompetencije nastavnika i barijere u interkulturalnoj komunikaciji [Teachers' Intercultural Competences and Barriers in Intercultural Communication]. In Posavec, K. \& Sablić, M. (eds.). Pedagogija i kultura - Zbornik radova Interkulturalna pedagogija: prema novim razvojima znanosti o odgoju (str. 83-92). Zagreb: Hrvatsko pedagogijsko društvo.

Đuranović, M., \& Klasnić, I. (2012). Interkulturalna kompetencija učitelja u primarnom obrazovanju - pravilo ili izuzetak? [Intercultural Competence of Initial Education Teachers - Rule or Exception?]. U Posavec, K. \& Sablić, M. (eds.). Pedagogija i kultura - Zbornik radova Interkulturalna pedagogija: prema novim razvojima znanosti o odgoju (str. 93-99). Zagreb: Hrvatsko pedagogijsko društvo.

Ewing, J. N. (2001). Teacher Education: Ethics, Power, and Privilege. Teacher Education and Special Education, 24(1), 13-24

Fives, H., \& Buehl, M. M. (2016). Teachers' Beliefs, in the Context of Policy Reform. Policy Insights from the Behavioral and Brain Sciences, 3(1), 114-121.

Gay, G. (2000). Culturally responsive teaching: Theory, research, and practice. New York: Teachers College Press.

Gay, G. (2002). Preparing for culturally responsive teaching. Journal of Teacher Education, 53, 106-116.

Gošović, R. (2009). Interkulturalno obrazovanje [Intercultural education]. In Aksentijević, Z. (eds.). Ne prolazi ulicom bez traga: ka interkulturalnosti (str. 7-20). Beograd: Grupa 484.

Hercigonja, Z. (2017). Interkulturalni odgoj i obrazovanje kao imperativ razvoja interkulturalnih kompetencija [Intercultural education and education as imperative for the development of intercultural competencies]. Socijalne teme, 4(4), 103-115.

Hollins, R. E. (2011). Teacher Preparation For Quality Teaching. Journal of Teacher Education, 62(4), 395-407.

Hrvatić, N. (2007). Interkulturalna pedagogija: nove paradigme [Intercultural pedagogy: new paradigms]. Pedagogijska istraživanja, 4(2), 241-254.

Hrvatić, N., i Piršl, E. (2005), Kurikulum pedagoške izobrazbe i interkulturalne kompetencije učitelja [Curriculum of pedagogical training and intercultural competence of teachers]. Pedagogijska istraživanja, 2(2), 256-266.

Jokikokko, K. (2009). The role of significant others in the intercultural learning of teachers. Journal of research in international education, 8(2), 142-163.

Lanas, M. (2014). Failing intercultural education? 'Thoughtfulness' in intercultural education for student teachers. European Journal of Teacher Education, 37(2), 171-182.

MacPherson, S. (2010). Teachers' Collaborative Conversations About Culture: Negotiating Decision Making in Intercultural Teaching. Journal of Teacher Education, 61(3), 271-286.

McAllister, G., \& Irvine, J. (2000). Cultural competency and multicultural teacher education. Review of Educational Research, 70(1), 3-24.

Müller, R. (2001). Teacher Training with Emphasis on Immigrant Pedagogy: Statement of Reasons and Curricular Building Blocks. European Education, 33(3), 54-67.

Perotti, A. (1995). Pledoaje za interkulturalni odgoj i obrazovanje [A plaidoyer for intercultural education]. Zagreb: Eduka.

Piršl, E. (2005). Verbalna i neverbalna interkulturalna komunikacija [Verbal and non-verbal intercultural communication]. U: Benjak, M. \& Požgaj Hadži, V. (ur.): Bez predrasuda i stereotipa (str. 50-90). Rijeka: Izdavački centar Rijeka. 
Šnel, R. (2008). Leksikon savremene kulture - Teme i teorije, oblici i institucije od 1945. do danas [The Lexicon of Contemporary Culture - Themes and Theories, Forms and Institutions from 1945 to the Present]. Beograd: Plato Books.

Vranješević, J., \& Frost, D. (2016). Stories From Intercultural Education in Serbia: Teacher Leadership and Parent Participation. European Education, 48, 63-78.

Whitaker, T., \& Kenny, M. (2016). Assessing Students' Journeys From Theory To Practice In Intercultural Education. All Ireland Journal of Teaching and Learning in Higher Education (AISHE-J), 8(2), 2551-2521.

\section{RAZVOJ KOMPETENCIJA NASTAVNIKA ZA INTERKULTURALNO OBRAZOVANJE}

Interkulturalno obrazovanje predstavlja sastavni deo reforme školskog sistema naše zemlje. U radu će biti ukazano na kompetencije koje je potrebno razviti kod nastavnika za uspešnu realizaciju koncepta interkulturalnog obrazovanja. Posebna pažnja biće posvećena sagledavanju ključnih elemenata koje bi inicijalna obuka nastavnika na nastavničkim fakultetima za interkulturalno obrazovanje trebalo da sadrži, s obzirom na to da razvijanje interkulturalnih kompetencija nastavnika predstavlja osnovu za rad na razvoju interkulturalnih kompetencija kod učenika. Kako bi se razvile potrebne kompetencije nastavnika, pored kvalitetnog inicijalnog obrazovanja, nužno je i kontinirano profesionalno usavršavanje nastavnika. U radu će biti istaknut značaj razvoja određenih nastavničkih kompetencija i biće ukazano na neke od pretpostavki uspešnog rada nastavnika na ostvarivanju interkulturalnog obrazovanja.

Ključne reči: interkulturalizam, interkulturalno obrazovanje, interkulturalne kompetencije nastavnika, obuka nastavnika za interkulturalnost 